\title{
THE EFFECTS OF SQUALENE ON THE INCORPORATION OF ACETATE INTO PLASMA CHOLESTEROL IN MAN ${ }^{1}$
}

\author{
By J. S. MCGUIRE, JR., ${ }^{2}$ AND S. R. LIPSKY 8 \\ (From the Department of Internal Medicine, Yale University School of Medicine, \\ New Haven, Conn.)
}

(Submitted for publication November 3, 1954; accepted January 12, 1955)

Squalene is an unsaturated C30 H50 hydrocarbon found in the liver of the basking shark, and in human sebum and skin. Its relationship to cholesterol metabolism was first noted by Channon (1), who, in 1926, observed an increase in the cholesterol content of the livers of rats maintained on a squalene diet. Simultaneously, Heilbron, Kamm, and Owens (2), while studying the structure of this material, postulated that squalene might be an intermediate in the biosynthesis of cholesterol. More recently, with the aid of radioisotopes, Srere (3) demonstrated a significant decrease in the conversion of $\mathrm{C}^{14}$-acetate

1 This work was supported by U. S. Public Health Service Grant A-254(C2) of the National Institute of Arthritis and Metabolic Diseases and by the Caming, Liebmann and Perlman funds.

2 This article represents work done in part as a James Hudson Brown Memorial Junior Fellow, in fulfillment of the thesis requirement for the degree of Doctor of Medicine at the Yale University School of Medicine.

3 U. S. Public Health Service Postdoctorate Research Fellow, National Heart Institute, 1952-1954. At present, Postdoctorate Research Fellow of the National Foundation for Infantile Paralysis. to cholesterol in liver slices prepared from rats fed 1 per cent squalene. Langdon and Bloch $(4,5)$ confirmed and expanded these studies and concluded that since labeled squalene is rapidly and efficiently converted to cholesterol, suppression of acetate incorporation into this steroid is the result of the preferential utilization of squalene as a cholesterol precursor.

The present investigation was undertaken to elucidate the role of squalene in the synthesis of plasma cholesterol from acetate in man.

\section{MATERIALS AND METHODS}

This study was performed on eight subjects with limited life expectancy. All were considered to be in a good nutritional state and on the basis of clinical and laboratory criteria were free from apparent metabolic disturbances. Pertinent data on these patients are listed in Table I.

Two hundred microcuries of sodium acetate-1-C $\mathrm{C}^{14}$ with a specific activity of $1.0 \mathrm{mc}$ per $\mathrm{mM}$ were given orally in the postabsorptive state to all subjects.4 Patient

4 This was authorized by the Isotopes Division, U. S. Atomic Energy Commission.

TABLE I

Clinical and laboratory data

\begin{tabular}{|c|c|c|c|c|c|c|c|c|c|}
\hline \multirow{3}{*}{ A } & \multirow{3}{*}{ 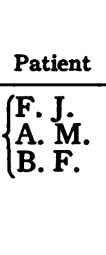 } & \multirow{3}{*}{$\begin{array}{r}\text { Age } \\
56 \\
45 \\
54\end{array}$} & \multirow{3}{*}{$\begin{array}{l}\text { Sex } \\
\mathbf{M} \\
\mathbf{M} \\
\mathbf{M}\end{array}$} & \multirow{3}{*}{$\begin{array}{c}\begin{array}{c}\text { Weight } \\
\text { kilograms }\end{array} \\
65.5 \\
74.6 \\
56\end{array}$} & \multirow{3}{*}{$\begin{array}{l}\text { Diagnosis } \\
\text { Carcinoma of lung } \\
\text { Carcinoma of lung } \\
\text { Carcinoma of lung }\end{array}$} & \multirow{2}{*}{\multicolumn{2}{|c|}{$\begin{array}{c}\begin{array}{c}\text { Total } \\
\text { cholesterol } \\
\text { mg. \% }\end{array} \\
200 \\
230 \\
173\end{array}$}} & \multirow{2}{*}{\multicolumn{2}{|c|}{$\begin{array}{c}\begin{array}{c}\text { Free } \\
\text { cholesterol } \\
\text { mg. \% }\end{array} \\
55 \\
67 \\
45\end{array}$}} \\
\hline & & & & & & & & & \\
\hline & & & & & & $\begin{array}{r}\text { Before } \\
\text { Squ }\end{array}$ & $\begin{array}{l}\text { After } \\
\text { ene }\end{array}$ & $\begin{array}{r}\text { Before } \\
\text { Squ }\end{array}$ & $\begin{array}{l}\text { After } \\
\text { lene }\end{array}$ \\
\hline B & $\left\{\begin{array}{l}\text { H. F. } \\
\text { J. M. } \\
\text { J. R. }\end{array}\right.$ & $\begin{array}{l}35 \\
62 \\
47\end{array}$ & $\begin{array}{l}\mathbf{F} \\
\mathbf{M} \\
\mathbf{M}\end{array}$ & $\begin{array}{l}60 \\
58 \\
70\end{array}$ & $\begin{array}{l}\text { Carcinoma of breast } \\
\text { Carcinoma of tonsil } \\
\text { Carcinoma of lung }\end{array}$ & $\begin{array}{l}253 \\
178 \\
135\end{array}$ & $\begin{array}{l}248 \\
180 \\
174\end{array}$ & $\begin{array}{l}70 \\
49 \\
44\end{array}$ & $\begin{array}{l}76 \\
47 \\
50\end{array}$ \\
\hline C & $\int \begin{array}{l}\text { J. R. } \\
\text { N. D. }\end{array}$ & $\begin{array}{l}47 \\
25\end{array}$ & $\begin{array}{l}\mathbf{M} \\
\mathbf{M}\end{array}$ & $\begin{array}{l}70 \\
55.5\end{array}$ & $\begin{array}{l}\text { Carcinoma of lung } \\
\text { Functioning carcinoma } \\
\text { of adrenal-removed } \\
1 \text { month prior to study } \\
\text { Carcinoma of colon }\end{array}$ & $\begin{array}{l}164 \\
176\end{array}$ & $\begin{array}{l}179 \\
184\end{array}$ & $\begin{array}{l}51 \\
50\end{array}$ & $\begin{array}{l}58 \\
49\end{array}$ \\
\hline
\end{tabular}

* Control study-Group B.

† Repeat study-Group C. 
J.R. was used as his own control and received a second dose of sodium acetate-1-C $C^{\text {16 }}$ eight weeks after the initial dose. Since approximately 56 per cent of $\mathrm{C}^{\mathbf{1 4}}$ given as acetate is eliminated as expired $\mathrm{C}^{14} \mathrm{O}_{2}$ within the first 24 hours (6), it was felt that the radiation resulting from the retained isotope was far below the accepted radiation tolerance level of 0.3 rep per week.

The subjects were divided into three groups:

Group $A$ (Pts. F. J., A. M., B. F.) received $200 \mathrm{mi}-$ crocuries of sodium acetate-1- $\mathrm{C}^{24}$.

TABLE II

Specific activity* of plasma cholesterol

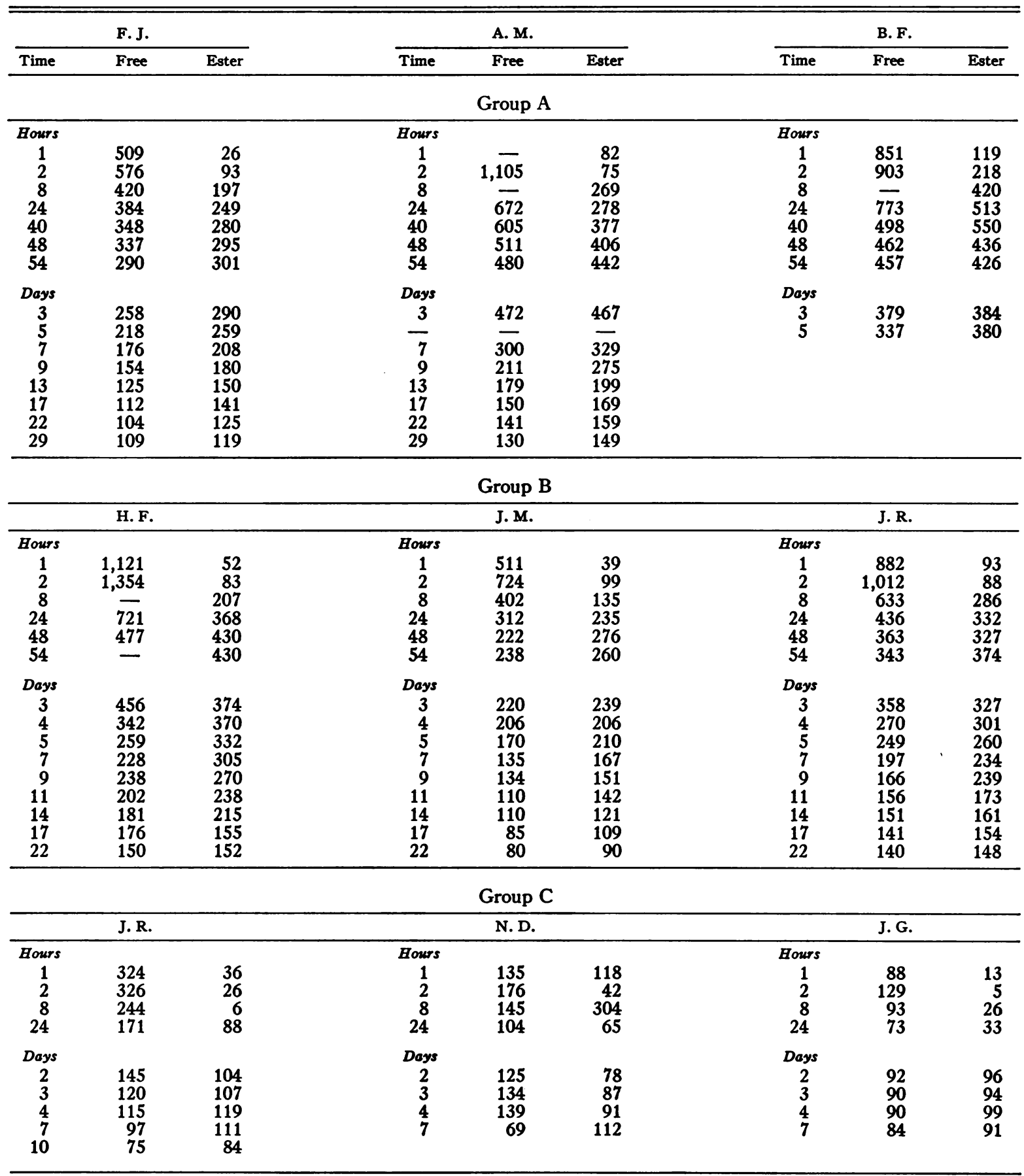

\footnotetext{
* Specific activity = disintegrations per mg. plasma cholesterol.
} 
Group B (Pts. H. F., J. M., J. R.) were fed 25 grams of squalene per day in divided doses for five days beginning 72 hours after the administration of 200 microcuries of 1-Cit acetate.

Group C (Pts. J. R., N. D., J. G.) received 25 grams of squalene per day in divided doses for five days. On the morning of the fourth day of squalene feeding, 200 microcuries of sodium acetate-1-C $\mathrm{C}^{\mathbf{1 4}}$ were given as described.

All subjects were maintained on normal dietary intakes during the course of the investigation.

Serial blood samples were taken in heparinized syringes at measured intervals beginning one hour after the administration of the acetate. In some cases the sampling continued for as long as 29 days. The specific activity of the plasma $\mathrm{C}^{\mathbf{1 4}}$ cholesterol fractions was determined according to the method of Rosenfeld, Hellman, Considine, and Gallagher (7). Radioactive assay was done in a windowless flow proportional counter. All counts were corrected for self absorption and by the use of absolute standards, converted to disintegrations per minute per mgm. cholesterol. The standard error in the net sample measurement was no greater than 5 per cent. This corresponded to a 3.4 per cent probable error. Blood for measurements of quantitative plasma cholesterol fractions was obtained at the beginning of each study and analyzed by the method of Man and Peters (8). In the two squalene fed groups (B and C) the cholesterol content of the plasma was determined at the beginning and end of the feeding period.

The squalene administered in this study was redistilled 'natural' squalene 5 emulsified with an equal volume of acacia and flavored with spearmint. It was estimated that the quantities fed per day comprised approximately 4 per cent of the daily dietary solids. There were no ill effects following the ingestion of this substance.

\section{RESULTS}

The serial specific activities of the free and esterified plasma $\mathrm{C}^{14}$ cholesterol of the control subjects (Group A) are given in Table IIA. The variations in activity of a typical patient (A. M.) followed for twenty-nine days are depicted as a

S Squalene supplied by Dr. Stanley Ames of Distillation Products Industries, Rochester, N. Y.

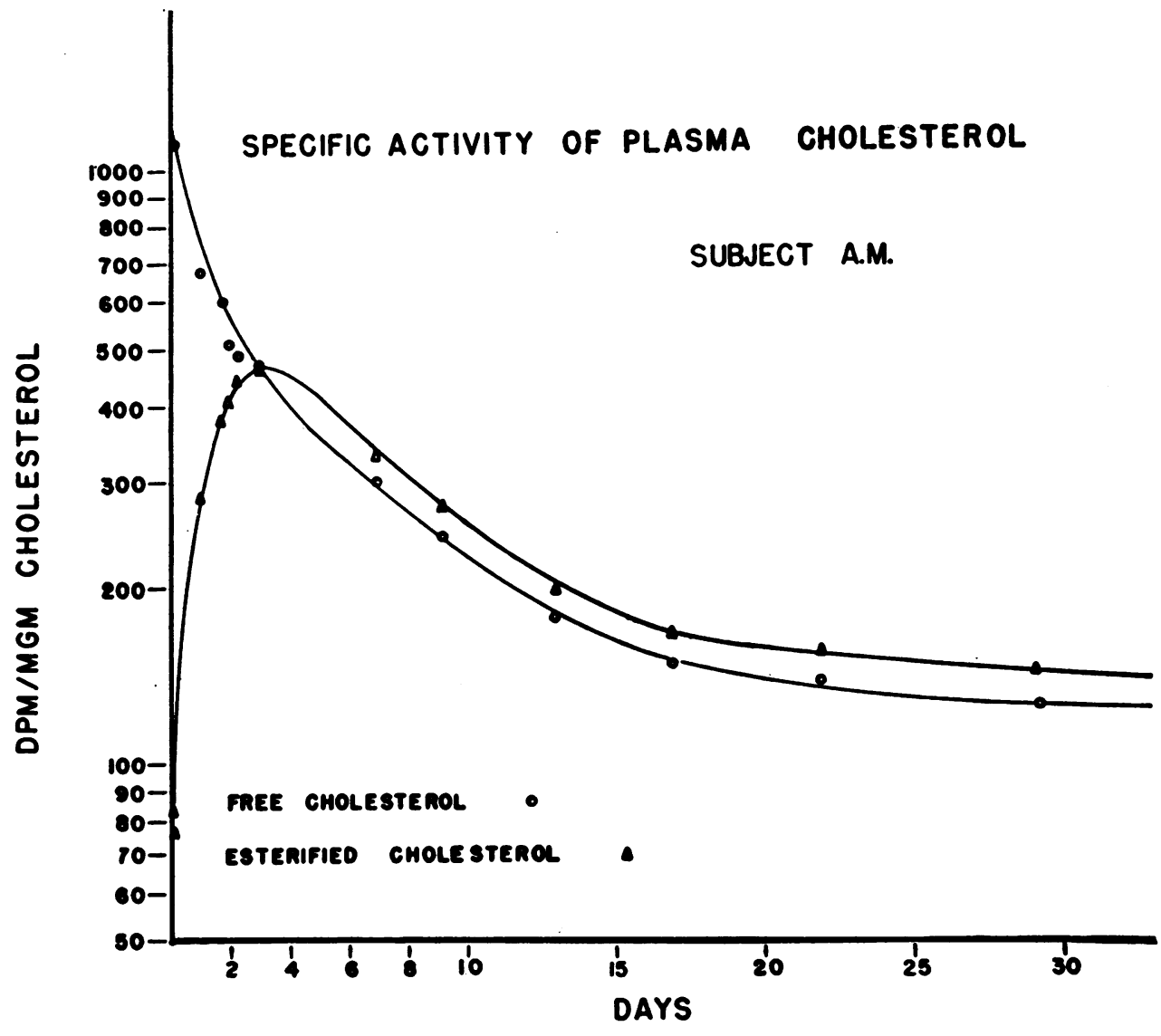

Fig. 1. Semilogarithmic Plot of the Incorporation of Carbon 14 into Plasma Free and Esterified Cholesterol Following the Administration of 200 Microcuries of AcEtate-1-C 14 to Subject A. M. of Group A 
SQUALENE AND PLASMA CHOLESTEROL IN MAN

TABLE III

Acetate utilization in the biosynthesis of plasma cholesterol

\begin{tabular}{|c|c|c|c|c|c|}
\hline & Patient & $\begin{array}{l}\text { \% in free } \\
\text { cholesterol* }\end{array}$ & $\begin{array}{l}\% \text { in ester } \\
\text { cholesterolt }\end{array}$ & $\begin{array}{l}\text { \% in total } \\
\text { cholesterol }\end{array}$ & \\
\hline A & $\left\{\begin{array}{l}\text { F. J. } \\
\text { B. F. } \\
\text { A. M. }\end{array}\right.$ & $\begin{array}{l}0.212 \\
0.227 \\
0.565\end{array}$ & $\begin{array}{l}0.0905 \\
0.1600 \\
0.0992\end{array}$ & $\begin{array}{l}0.3025 \\
0.3870 \\
0.6640\end{array}$ & \multirow{2}{*}{$\begin{array}{l}\text { Groups A and B } \\
\text { Range: } 0.3025 \text { to } 0.6930 \\
\text { Average } \% \text { in total circulating plasma cholesterol }=0.4514\end{array}$} \\
\hline B & $\left\{\begin{array}{l}\text { H.F. } \\
\text { J.M } \\
\text { J.R. }\end{array}\right.$ & $\begin{array}{l}0.603 \\
0.209 \\
0.322\end{array}$ & $\begin{array}{l}0.0931 \\
0.0755 \\
0.0575\end{array}$ & $\begin{array}{l}0.6930 \\
0.2845 \\
0.3775\end{array}$ & \\
\hline C & $\left\{\begin{array}{l}\text { J. R. } \\
\text { N. D. } \\
\text { J. G. }\end{array}\right.$ & $\begin{array}{l}0.1198 \\
0.0503 \\
0.0342\end{array}$ & $\begin{array}{l}0.0234 \\
0.0298 \\
0.0036\end{array}$ & $\left.\begin{array}{l}0.1428 \\
0.0798 \\
0.0376\end{array}\right\}$ & $\begin{array}{l}\text { Group C } \\
\text { Range: } 0.0376 \text { to } 0.1428 \\
\text { Average } \% \text { in total circulating plasma cholesterol }=0.0867\end{array}$ \\
\hline
\end{tabular}

* Per cent incorporation of radioactivity into total circulating free cholesterol at two hours.

† Per cent incorporation of radioactivity into total circulating ester cholesterol at two hours.

semilogarithmic plot in Figure 1. These curves closely resemble those described by Hellman, Rosenfeld, and Gallagher (9) using similar techniques. In this series, the peak activity of the plasma free $\mathrm{C}^{14}$ cholesterol invariably occurred in the two-hour sample. The peak activity for the ester $\mathrm{C}^{14}$ cholesterol fraction was usually reached between two and two and one-half days. At this point, the specific activity curve of the ester cholesterol intersected that of the free cholesterol and then diminished at a comparable rate of decay.

In the Group B subjects who received squalene three days after the administration of $1-\mathrm{C}^{14}$ acetate, the curves of the serial specific activities of the free and esterified plasma cholesterol (Table IIB) were essentially identical with those of the control group. It should be noted that squalene was not introduced until maximum labeling of both cholesterol fractions had already occurred and at a point where the activities of these steroids were decaying in an exponential fashion.

The most striking results were noted in the subjects who had ingested squalene prior to and after the administration of radioactive acetate (Table IIC). In comparison with Groups A and B, there was an average five-fold decrease in the per cent of acetate-1- $\mathrm{C}^{14}$ entering the total circulating plasma as labeled cholesterol at two hours (Table III). This reduction in incorporation varied from two to twenty-three-fold.

In subject J. R. who served as his own control (Figure 2) a two and one-half-fold decrease was seen at two hours. At the intersects, when the activity of the free cholesterol begins to decay at a rate comparable to that of the ester, similar degrees of depression prevailed.
Patients in Group C, particularly N. D. and J. G., exhibited atypical specific activity curves. This probably reflects irregularities in squalene absorption from the gastrointestinal tract with subsequent alterations in size of the squalene pool.

In four of the six patients who received squalene, small rises in the total plasma cholesterol were seen (Table I). Except for J. R., these results are of doubtful significance. However, these findings are in the same direction as those of Srere (3) who observed elevations of total cholesterol in the plasma of squalene fed dogs.

\section{DISCUSSION}

Acetate molecules apparently provide the major source of carbon for the synthesis of cholesterol in man and animal; however the mechanism by which $2 \mathrm{C}$ fragments condense to form cholesterol precursors of high molecular weights has only recently begun to be understood. Although Zabin and Bloch $(10,11)$ showed that carbon atoms derived from isovalerate and butyrate were efficiently incorporated into the sterol nucleus, these compounds are not true intermediates since the conversion probably took place through the formation of "active acetate." The isoprenoid triterpene squalene has been proposed as an intermediate of cholesterol (1-3). Langdon and Bloch (4, 5 ) isolated radioactive squalene from the tissues of squalene fed rats who received $\mathrm{C}^{14}$ labeled acetate. When this tagged substance, which had all the biochemical characteristics of natural squalene, was fed to rats, it was found to be the most potent cholesterol precursor known to date.

If the absorption data obtained from these ex- 
periments are applied to our studies (see Appendix), it can be roughly estimated that about 20 per cent of the liver cholesterol formed during the feeding period was derived from squalene. Since squalene has not as yet been isolated from the liver of humans, if it exists as an obligatory intermediate, it must occur in very small quantities and turn over with great rapidity. Thus in the subjects who were prefed squalene (Group C) the two-to twenty-three-fold depression in incorporation of acetate to cholesterol may be attributed to a dual mechanism. Exogenous squalene probably dilutes the "higher intermediate" pool between acetate and cholesterol thus displacing acetate as a source of cholesterol and permitting it to be rerouted and utilized along other metabolic path-

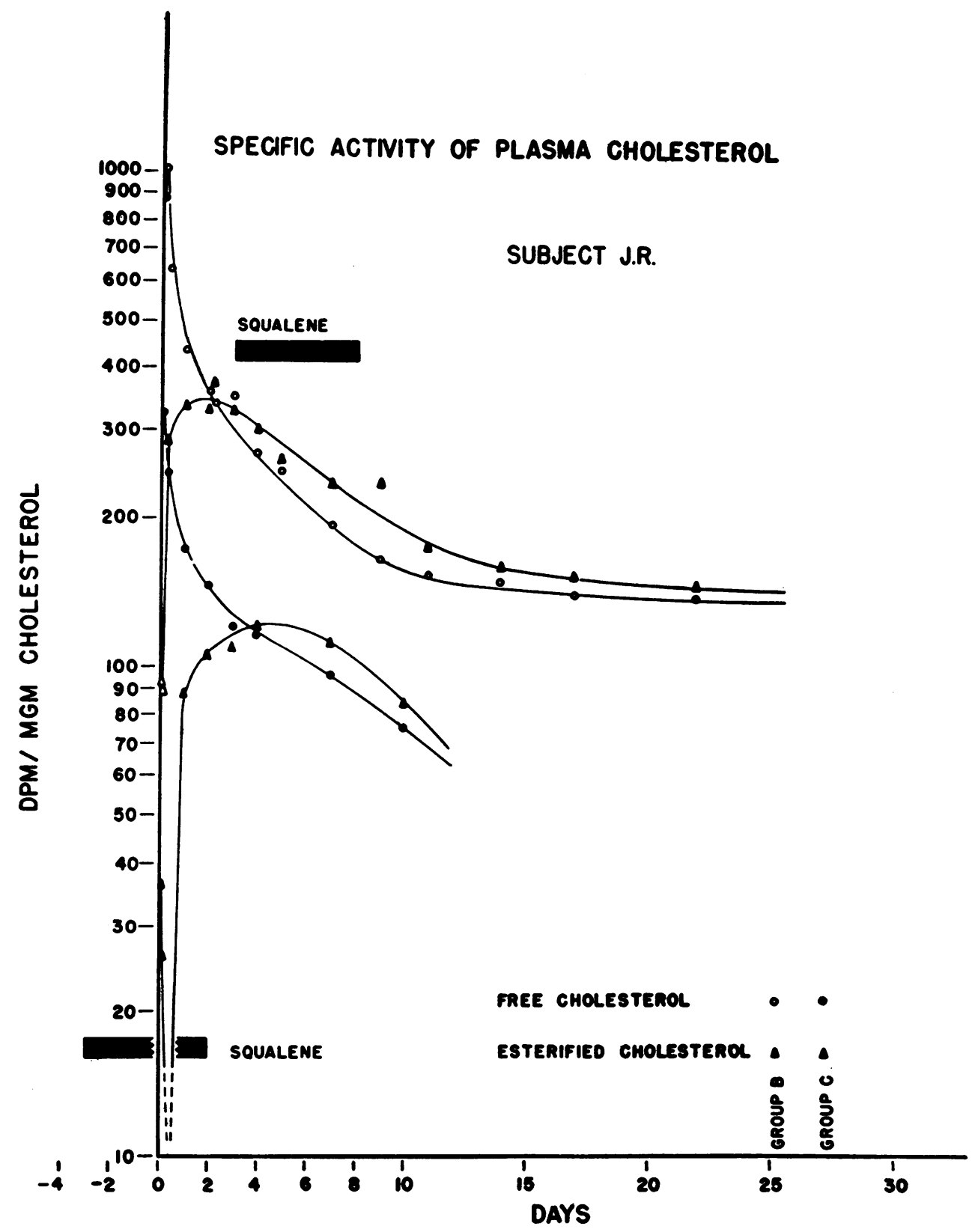

Fig. 2. Semilogarithmic Plot of the Incorporation of Carbon 14 into Plasma Free and Esterified Cholesterol of Patient J. R. Following the Administration of 200 Microcuries of Acetate-1-C ${ }^{14}$ Showing the Effect of Prefeeding with Squalene 
ways. Moreover the plasma cholesterol rose slightly in four of the six subjects receiving squalene. Since the liver is the major source of plasma cholesterol (14) it seems reasonable to assume that similar changes occurred in this organ. Indeed, both Channon and Srere $(1,3)$ observed considerable increases in the total hepatic cholesterol content of squalene fed rats. Squalene, by causing a "piling up" of hepatic cholesterol, may therefore evoke a homeostatic reduction in cholesterol synthesis from all sources (15).

The lack of appreciable changes in the specific activities of carbon ${ }^{14}$ cholesterol in the patients who comprised Group B can be readily explained. Since these subjects received their squalene at a time when all of the available radioactive acetate had already been assimilated into the cholesterol molecule, no depression in peak activities could occur. Moreover, the increases in cholesterol caused by five days of squalene feeding at the 4 per cent dose level were insufficient to produce a detectable "dilution effect." The segment of the curve that is decaying exponentially (about the 4th to the 15th day) thus remains unaltered.

\section{SUMMARY}

The daily administration of 4 per cent squalene for five days to three subjects who received sodium acetate-1- $\mathrm{C}^{14}$ in the middle of the feeding period resulted in a two- to twenty-three-fold depression in the synthesis of $\mathrm{C}^{14}$ plasma cholesterol from this 2 carbon fragment.

Suppression of acetate incorporation by squalene feeding is probably the result of dilution of the higher intermediate pool between acetate and cholesterol.

\section{ACKNOWLEDGMENTS}

The authors wish to extend their deep appreciation to Dr. Evelyn Man for the determinations of plasma cholesterol, to Dr. Paul Kunkel of the West Haven Veterans Administration Hospital for the use of some of his patients, and to Dr. Leon Hellman of the Sloan-Kettering Institute for the method used in the determination of radioactive cholesterol.

\section{APPENDIX}

\section{An approximation of the quantity of liver cholesterol derived from squalene in man}

Absorption of squalene from GI tract (5)

Per cent of absorbed squalene going to liver cholesterol (5)

Total liver cholesterol in man-two cases at necropsy (12)

Per cent of total liver cholesterol as the free fraction (12)

Quantity of free cholesterol derived from squalene

In comparison to dogs, if it is assumed that the delay in appearance of the peak specific activity in the plasma free cholesterol in man is also reflected in the hepatic fraction, then the half life of the free cholesterol in the liver of man is approximately twice that found in dogs (13) or about 14 hours.

Thus, the turnover time $\overline{\mathrm{T}}=t \frac{1}{2} \times \mathrm{k}$

$$
\overline{\mathrm{T}}=14 \mathrm{hrs} . \times 1.44=20 \text { hours }
$$

then per cent turnover per hour $=1 / \overline{\mathrm{T}}$ or 5 per cent; therefore the absolute turnover expressed as mg. of free cholesterol of the liver $=5$ per cent of 3.38 grams or $169 \mathrm{mg}$. per hr. or 4.06 grams per day.

\section{REFERENCES}

1. Channon, H. J., The biological significance of unsaponifiable matter of oils. I. Experiments with the unsaturated hydrocarbon squalene (spinacene). Biochem. J., 1926, 20, 400.

2. Heilbron, I. M., Kamm, E. D., and Owens, W. M., The unsaponifiable matter from the oils of elasmobranch fish. Part I. A contribution to the study of the constitution of squalene (spinacene). J. Chem. Soc., 1926, p. 1630.

3. Srere, P. A., Biosynthesis of cholesterol. Doctoral Dissertation, University of California, 1951.
50 per cent or $12.5 \mathrm{gm}$. 8 per cent or $1.0 \mathrm{gm}$. ave. $4.04 \mathrm{gm}$. 83.8 per cent or $3.38 \mathrm{gm}$. $0.84 \mathrm{gm}$.

. 
8. Man, E. B., and Peters, J. P., Gravimetric determination of serum cholesterol adapted to the Man and Gildea fatty acid method, with a note on the estimation of lipoid phosphorus. J. Biol. Chem., 1933, $101,685$.

9. Hellman, L., Rosenfeld, R. S., and Gallagher, T. F., Cholesterol synthesis from $\mathrm{C}^{14}$-acetate in man. $\mathrm{J}$. Clin. Invest., 1954, 33, 142.

10. Zabin, I., and Bloch, K., The utilization of isovaleric acid for the synthesis of cholesterol. J. Biol. Chem., 1950, 185, 131.

11. Zabin, I., and Bloch, K., The utilization of butyric acid for the synthesis of cholesterol and fatty acids. J. Biol. Chem., 1951, 192, 261.
12. Ralli, E. P., Rubin, S. H., and Rinzler, S., The liver lipids in normal human livers and in cases of cirrhosis and fatty infiltration of the liver. J. Clin. Invest., 1941, 20, 93.

13. Harper, P. V., Jr., Neal, W. B., Jr., and Hlavacek, G. R., Lipids synthesis and transport in the dog. Metabolism, 1953, 2, 69.

14. Byers, S. O., Friedman, M., and Rosenman, R. H., Review: On the regulation of blood cholesterol. Metabolism, 1952, 1, 479.

15. Tomkins, G. M., Sheppard, H., and Chaikoff, I. L., Cholesterol synthesis by liver. III. Its regulation by ingested cholesterol. J. Biol. Chem., 1953, 201, 137. 